\title{
Simultaneous Determinations of Plasma ACTH and GH Levels after an Oral Metyrapone*
}

\author{
Shinji SAWANO, Tokuko SAITO and KazUo SHIZUME \\ AND KaZUO TAKEBE** \\ Department of Endocrinology, Toranomon Hospital, Tokyo and \\ **The second Department of Medicine, Hokkaido University School of Medicine, \\ Sapporo, Hokkaido
}

\section{Synopsis}

\begin{abstract}
The levels of plasma ACTH and GH were simultaneously measured in normal subjects every $30 \mathrm{~min}$ for $4 \mathrm{hr}$ after an oral administration of metyrapone, either $1.0 \mathrm{~g}$ or $1.5 \mathrm{~g}$. Both doses of metyrapone caused a significant decrease in plasma cortisol levels 90 min later, when the mean values of plasma cortisol levels were not significantly different between both groups. An administration of $1.0 \mathrm{~g}$ of metyrapone raised plasma ACTH levels in 2 out of 6 subjects within 90 min, while an increase in plasma GH levels of 5.0 $\mathrm{ng} / \mathrm{m} l$ above the base line levels was observed in 2 subjects. In one of the subjects in whom the levels of plasma $\mathrm{GH}$ increased, plasma $\mathrm{GH}$ peak was preceded by that of plasma ACTH, but no rise in plasma ACTH levels was observed in another subject. When $1.5 \mathrm{~g}$ of metyrapone was given, plasma ACTH levels increased in all 6 subjects. The response of plasma ACTH was quite different in each individual and there appeared one or two peaks within $240 \mathrm{~min}$. The mean value of plasma ACTH was $69 \pm 17 \mathrm{pg} / \mathrm{m} l$ at 0 time and increased to $165 \pm 18 \mathrm{pg} / \mathrm{m} l$ at $60 \mathrm{~min}$ ( $\mathrm{p}<0.01 \mathrm{vs} 0$ time). An increment in plasma GH levels was observed in 5 out of 6 subjects. The mean peak value was reached at $90 \mathrm{~min}$ and the difference between the values at 0 and $90 \mathrm{~min}$ was significant. There was also no correlation between the secretion of ACTH and that of GH. These results may indicate that a higher dose of metyrapone causes both ACTH and GH secretions within a short period not by a negative feedback mechanism of cortisol but presumably by acting directly on the pituitary and/or on the hypothalamus as a nonspecific stimulus.
\end{abstract}

Metyrapone is known to stimulate the release of ACTH by a negative feedback mechanism of cortisol and widely used for testing the hypothalamo-pituitary axis. In the previous study (Kunita et al., 1970), we reported an oral administration of $1.5 \mathrm{~g}$ of metyrapone induced an increase in plasma $\mathrm{GH}$ levels in normal subjects. Since the rise in plasma $\mathrm{GH}$ was not suppressed in the subjects pretreated with dexamethasone, it was considered that the response of $\mathrm{GH}$ might not be related to a negative feedback mechanism through which metyrapone stimulated

Received for publication September 15, 1972.

* This study was supported in part by a grant from the Ministry of Education, Japan.
ACTH release. In order to conclude the possibility, however, a relationship between $\mathrm{ACTH}$ and $\mathrm{GH}$ responses to metyrapone should be elucidated. On the other hand, ACTH levels within a short period following an oral administration of relatively large dose of metyrapone have not been well understood. It seems, therefore, to be of interest to measure simultaneously both hormones in plasma after metyrapone.

\section{Materials and Methods}

Ten healthy male college students, aged 19-22 were studied. Their body weights ranged $53-61 \mathrm{~kg}$. After an overnight fast 6 subjects were given $1.0 \mathrm{~g}$ of 
metyrapone orally at 9:00 a.m. One week later, 2 out of the 6 subjects and other 4 subjects received $1.5 \mathrm{~g}$ of metyrapone in the same manner. They were at bed rest for $30 \mathrm{~min}$ before and throughout the study. Thirty min prior to the initiation of blood sampling, an indwelling needle was inserted into a forearm vein. Blood samples for the estimation of plasma ACTH, $\mathrm{GH}$ and cortisol were obtained immediately before and every $30 \mathrm{~min}$ for $4 \mathrm{hr}$ following. Plasma ACTH was measured by a radioimmunoassay according to Berson and Yalow (1968). The minimal detectable dose of ACTH was as low as $2.5 \mathrm{pg} /$ tube in this assay system. Plasma GH was determined by a double antibody radioimmunoassay (Schalch and Parker, 1964) and plasma cortisol by the method of Rudd et al. (1963). For the evaluation of plasma $\mathrm{GH}$ response, an increase in plasma $\mathrm{GH}$ levels of $5.0 \mathrm{ng} / \mathrm{m} l$ above the base line considered to be a positive response. Statistical calculations were made by Student $t$ test.

\section{Results}

Plasma cortisol levels, when a single dose of metyrapone, either 1.0 or $1.5 \mathrm{~g}$ was administered, are shown in Figure 1. The mean basal levels of plasma cortisol at 9:00 a.m. were $14.1 \pm 0.8 \mu \mathrm{g} / 100 \mathrm{ml}(1.0 \mathrm{~g}$ group $)$ and $13.3 \pm 1.9 \mu \mathrm{g} / 100 \mathrm{ml}(1.5 \mathrm{~g}$ group $)$. After 90 min the levels decreased sharply to $2.1 \pm 0.6$ $\mu \mathrm{g} / 100 \mathrm{ml}$ and to $0.8 \pm 0.3 \mu \mathrm{g} / 100 \mathrm{ml}$, respectively. Plasma cortisol levels at $90 \mathrm{~min}$ was not significantly different between both groups. The similar side effects appeared after $1.5 \mathrm{~g}$ of metyrapone, as we observed previously (Kunita et al., 1970), but they were less or none after $1.0 \mathrm{~g}$ of metyrapone.

Each individual data of plasma ACTH and $\mathrm{GH}$ levels after either 1.0 or $1.5 \mathrm{~g}$ of metyrapone is reported in Tables 1 and 2. The responses of plasma ACTH to $1.0 \mathrm{~g}$ of metyrapone were not uniform. In Subject 1 an initial rise in plasma ACTH appeared at $60 \mathrm{~min}$ and a second small peak at $180 \mathrm{~min}$. A similar sharp peak was observed in Subject 2 at $90 \mathrm{~min}$ and then rapidly decreased at $150 \mathrm{~min}$. On the contrary, plasma ACTH levels decreased in Subjects 3 and 5 during the first $90 \mathrm{~min}$, and increased at $240 \mathrm{~min}$ in Subjects 3. No clear changes in plasma ACTH

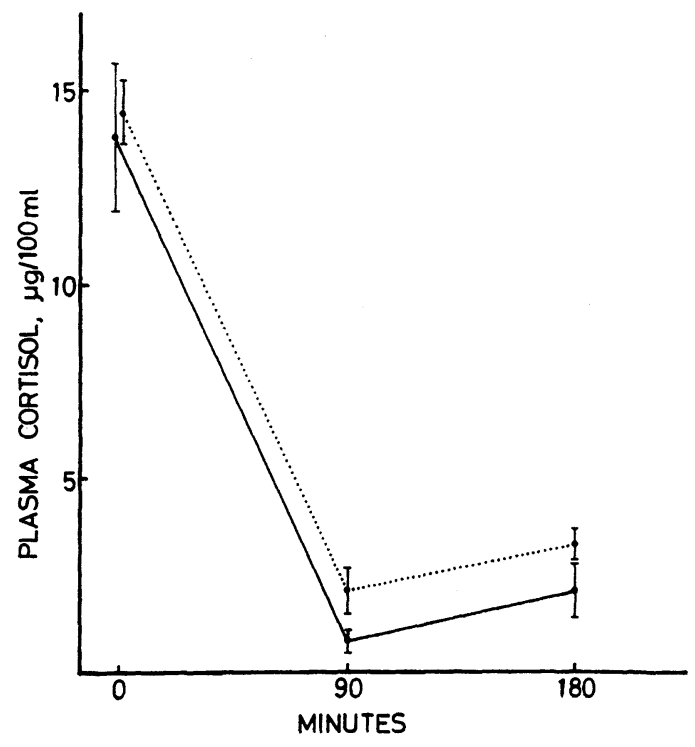

Fig. 1. Changes in plasma cortisol levels after administration of metyrapone orally at 0 time (9: 00 a.m.), either $1.0 \mathrm{~g}$ (dashed line) or $1.5 \mathrm{~g}$ (solid line). Brackets indicate standard errors.

levels were observed in Subjects 4 and 6 . Summerizing these individual observations, there is no consistent tendency in the levels of plasma ACTH after $1.0 \mathrm{~g}$ of metyrapone (Table 1). The response of plasma $\mathrm{GH}$ to $1.0 \mathrm{~g}$ of metyrapone was seen in Subjects 2 and 5 (Table 2). In Subject 2 plasma GH peak was preceded by that of plasma $\mathrm{ACTH}$, but no rise in plasma ACTH was observed in Subject 5 .

When $1.5 \mathrm{~g}$ of metyrapone was given, plasma ACTH levels increased in all subjects (Table 1). The magnitudes and the patterns of ACTH responses were different in each subject. An initial sharp rise in plasma ACTH was seen within $90 \mathrm{~min}$ in all subjects except Subject 8 in whom the level increased gradually to a maximal level at $120 \mathrm{~min}$. The responses of plasma ACTH to $1.5 \mathrm{~g}$ of metyrapone were similar in fashion to those to $1.0 \mathrm{~g}$ of metyrapone in Subjects 1 and 2, to whom the both doses of metyrapone were administered. However, when $1.5 \mathrm{~g}$ of 
Table 1. Effect of an oral administration of either 1.0 or $1.5 \mathrm{~g}$ of metyrapone on the levels of plasma ACTH

\begin{tabular}{|c|c|c|c|c|c|c|c|c|c|c|}
\hline \multirow{2}{*}{ Subject } & \multirow{2}{*}{\multicolumn{2}{|c|}{$\begin{array}{l}\text { Dose of metyrapone } \\
\text { total }(\mathrm{g}) \quad \mathrm{mg} / \mathrm{kg}\end{array}$}} & \multicolumn{8}{|c|}{ Plasma ACTH levels $(\mathrm{pg} / \mathrm{m} l)$} \\
\hline & & & 0 & 30 & 60 & 90 & 120 & 150 & 180 & $240 \mathrm{~min}$ \\
\hline 1. MA & 1.0 & 17.2 & 50 & 45 & 185 & 150 & 55 & - & 105 & 80 \\
\hline 2. $\mathrm{HO}$ & 1.0 & 16.7 & 10 & 25 & 45 & 270 & 135 & 25 & 50 & 90 \\
\hline 3. $\mathrm{KI}$ & 1.0 & 16.9 & 190 & 45 & 80 & 55 & 115 & 115 & 55 & 335 \\
\hline 4. WA & 1.0 & 17.5 & 65 & 65 & 90 & 45 & 120 & 65 & 45 & 80 \\
\hline 5. IK & 1.0 & 18.9 & 135 & 65 & 80 & 10 & 80 & 45 & 10 & 90 \\
\hline 6. SA & 1.0 & 18.1 & 90 & 90 & 115 & 90 & 115 & 90 & 80 & 90 \\
\hline $\begin{array}{l}\text { Mean } \\
\pm \text { S.E. }\end{array}$ & & & $\begin{array}{l}90 \\
\pm 26 \\
\end{array}$ & $\begin{array}{l}56 \\
\pm 9 \\
\end{array}$ & $\begin{array}{l}99 \\
\pm 19 \\
\end{array}$ & $\begin{array}{c}103 \\
\pm 39 \\
\end{array}$ & $\begin{array}{l}103 \\
\pm 12 \\
\end{array}$ & $\begin{array}{l}68 \\
\pm 16 \\
\end{array}$ & $\begin{array}{l}58 \\
\pm 13 \\
\end{array}$ & $\begin{array}{l}128 \\
\pm 42 \\
\end{array}$ \\
\hline 1. $\mathbf{M A}$ & 1.5 & 25.9 & 90 & 210 & 225 & 80 & 150 & 150 & 205 & 135 \\
\hline 2. $\mathrm{HO}$ & 1.5 & 25.0 & 10 & 80 & 135 & 245 & 205 & 245 & 115 & - \\
\hline 7. $\mathrm{MO}$ & 1.5 & 23.1 & 55 & 55 & 205 & 150 & 150 & 205 & 55 & 150 \\
\hline 8. HI & 1.5 & 24.6 & 135 & 150 & 150 & 170 & 240 & 170 & 135 & 335 \\
\hline 9. NI & 1.5 & 25.9 & 80 & 10 & 170 & 185 & 80 & 25 & 10 & 80 \\
\hline 10. AR & 1.5 & 27.8 & 45 & 55 & 105 & 55 & 25 & 150 & 90 & - \\
\hline $\begin{array}{l}\text { Mean } \\
\pm \text { S.E. }\end{array}$ & & & $\begin{array}{l}69 \\
\pm 17\end{array}$ & $\begin{array}{l}93 \\
\pm 30\end{array}$ & $\begin{array}{r}165^{* *} \\
\pm 18\end{array}$ & $\begin{array}{l}148^{*} \\
\pm 29\end{array}$ & $\begin{array}{l}142 \\
\pm 32\end{array}$ & $\begin{array}{l}158^{*} \\
\pm 30\end{array}$ & $\begin{array}{l}102 \\
\pm 27\end{array}$ & $\begin{array}{l}175 \\
\pm 55\end{array}$ \\
\hline
\end{tabular}

* p $<0.05$ vs 0 time; ** $\mathrm{p}<0.01$ vs 0 time.

Table 2. Effect of an oral administration of either 1.0 or $1.5 \mathrm{~g}$ of metyrapone on the levels of plasma $\mathrm{GH}$

\begin{tabular}{|c|c|c|c|c|c|c|c|c|c|c|}
\hline \multirow{2}{*}{ Subject } & \multirow{2}{*}{\multicolumn{2}{|c|}{$\begin{array}{l}\text { Dose of metyrapone } \\
\text { total }(\mathrm{g}) \mathrm{mg} / \mathrm{kg}\end{array}$}} & \multicolumn{8}{|c|}{ Plasma GH levels $(\mathrm{ng} / \mathrm{m} l)$} \\
\hline & & & 0 & 30 & 60 & 90 & 120 & 150 & 180 & $240 \mathrm{~min}$ \\
\hline 1. MA & 1.0 & 17.2 & $<0.5$ & 1.8 & 3.3 & 2.0 & 1.0 & 1.0 & 1.3 & 0.8 \\
\hline 2. $\mathrm{HO}$ & 1.0 & 16.7 & 0.5 & 2.0 & 1.6 & 1.2 & 1.1 & 5.6 & 6.2 & 1.6 \\
\hline 3. $\mathrm{KI}$ & 1.0 & 16.9 & 1.1 & 1.2 & 1.5 & 1.2 & 1.0 & 0.8 & 0.8 & 0.8 \\
\hline 4. WA & 1.0 & 17.5 & 0.5 & 0.5 & 1.0 & 0.5 & $<0.5$ & $<0.5$ & $<0.5$ & $<0.5$ \\
\hline 5. IK & 1.0 & 18.9 & 0.6 & 5.6 & 6.5 & 5.4 & 3.6 & 1.4 & 0.6 & $<0.5$ \\
\hline 6. SA & 1.0 & 18.1 & 0.6 & 3.6 & 4.4 & 1.8 & 0.6 & $<0.5$ & $<0.5$ & 0.7 \\
\hline $\begin{array}{l}\text { Mean } \\
\pm \text { S.E. }\end{array}$ & & & $\begin{array}{l}0.6 \\
\pm 0.12\end{array}$ & $\begin{array}{l}2.5 \\
\pm 0.8\end{array}$ & $\begin{array}{l}3.1 \\
\pm 0.9\end{array}$ & $\begin{array}{l}2.0 \\
\pm 0.7\end{array}$ & $\begin{array}{l}1.3 \\
\pm 0.5\end{array}$ & $\begin{array}{l}1.6 \\
\pm 0.8\end{array}$ & $\begin{array}{l}1.7 \\
\pm 0.9\end{array}$ & $\begin{array}{l}1.0 \\
\pm 0.2\end{array}$ \\
\hline 1. MA & 1.5 & 25.9 & 0.5 & 0.5 & 41.4 & 49.5 & 25.8 & 9.6 & 5.5 & 1.2 \\
\hline 2. $\mathrm{HO}$ & 1.5 & 25.0 & 0.8 & $<0.5$ & 0.5 & $<0.5$ & 2.9 & 2.7 & 1.2 & - \\
\hline 7. MO & 1.5 & 23.1 & $<0.5$ & $<0.5$ & 7.2 & 12.4 & 3.8 & 1.6 & 1.1 & $<0.5$ \\
\hline 8. HI & 1.5 & 24.6 & 0.7 & 0.6 & 6.0 & 7.4 & 5.4 & 1.4 & 0.5 & $<0.5$ \\
\hline 9. NI & 1.5 & 25.9 & $<0.5$ & $<0.5$ & 4.0 & 13.4 & 3.4 & 0.6 & $<0.5$ & $<0.5$ \\
\hline 10. AR & 1.5 & 27.8 & 0.6 & 0.6 & 0.9 & 3.9 & 5.7 & 2.8 & 0.7 & - \\
\hline $\begin{array}{l}\text { Mean } \\
\pm \text { S.E. }\end{array}$ & & & $\begin{array}{l}0.6 \\
\pm 0.1\end{array}$ & 0.5 & $\begin{array}{l}10.0^{*} \\
\pm 6.4\end{array}$ & $\begin{array}{r}14.5^{* *} \\
\pm 6.4\end{array}$ & $\begin{array}{l}7.8 \\
\pm 3.6\end{array}$ & $\begin{array}{l}4.4 \\
\pm 1.5\end{array}$ & $\begin{array}{l}1.6 \\
\pm 0.8\end{array}$ & $\begin{array}{l}0.7 \\
\pm 0.1\end{array}$ \\
\hline
\end{tabular}

* $\mathrm{p}<0.05$ vs 0 time; ** $\mathrm{p}<0.01$ vs 0 time.

Values below $0.5 \mathrm{ng} / \mathrm{m} l$ were considered as $0.5 \mathrm{ng} / \mathrm{m} l$ for statistical calculation. 
metyrapone was given, the level of the second ACTH peak was higher in Subject 1 and the duration of high levels of ACTH was longer in Subject 2 than when $1.0 \mathrm{~g}$ of metyrapone was given. A statistical analysis indicated that the levels of plasma ACTH increased significantly 60,90 and $150 \mathrm{~min}$ after $1.5 \mathrm{~g}$ of metyrapone (Table 1). The $\mathrm{GH}$ response to $1.5 \mathrm{~g}$ of metyrapone was observed in 5 out of 6 subjects (Table 2). The mean peak value was reached at $90 \mathrm{~min}$. The differences between the values at 0 and $90 \mathrm{~min}$ and between those at 0 and $60 \mathrm{~min}$ were statistically significant. No relationship was observed between the changes in plasma ACTH and GH.

\section{Discussion}

Recently Sawin et al. (1971) reported that a rise in plasma $\mathrm{GH}$ levels was not induced $120 \mathrm{~min}$ after $1.5 \mathrm{~g}$ of metyrapone under the similar condition as we previously described (Kunita et al., 1970). The GH response to metyrapone was reconfirmed in the present study, so that it is difficult to explain their negative results. Two explanations, however, could be possible. First, their subjects must have weighed more than ours, so $1.5 \mathrm{~g}$ of metyrapone might have not been enough to evoke GH release. The dose of metyrapone per $\mathrm{kg}$ body weight in each subject is shown in Tables 1 and 2. Second, since in the present study a statistically significant increment in plasma GH levels was observed 60 and 90 min after $1.5 \mathrm{~g}$ of metyrapone, and the value at 120 min was not significantly different. This may suggest that measuring once at $120 \mathrm{~min}$ is not enough to evaluate the action of metyrapone.

The present study clearly indicates that GH response to metyrapone is not related to ACTH secretion. This may also exclude the possibility that an increase in endogenous ACTH stimulates $\mathrm{GH}$ release, though Zahnd et al. (1969) have shown that the exogenous ACTH simulated the release of GH. With regard to the mechanism of metyrapone action on GH secretion, Bruno et al. (1971) found a significant negative correlation between the cortisol disappearance half time and the maximal increment in plasma $\mathrm{GH}$ after metyrapone. Since in the present study plasma cortisol levels were not measured 30 and 60 min after metyrapone, an exact pattern of the disappearance of plasma cortisol was not clear. However, despite the fact that the levels of plasma cortisol at $90 \mathrm{~min}$ were similar between the groups of $1.0 \mathrm{~g}$ and $1.5 \mathrm{~g}$ of metyrapone, the responses of plasma $\mathrm{GH}$ and ACTH in $1.0 \mathrm{~g}$ group were not significant, whereas the responses in $1.5 \mathrm{~g}$ group were significant. It is, therefore, unlikely that the releases of both $\mathrm{GH}$ and $\mathrm{ACTH}$ induced by metyrapone are due to a fall of plasma cortisol concentration.

Considering the mechanism of GH response to metyrapone, the "early rise" in plasma ACTH seen in the present study is quite interesting. Liddle (1960) originally suggested that metyrapone stimulated the secretion of ACTH through its inhibitory action on the $11 \beta$-hydroxylase activity in the adrenal cortex. Since then, numerous studies have indicated that when plasma ACTH levels were measured directly after metyrapone, it took at least 3-6 hr (Berson and Yalow, 1968) or longer (Berson and Yalow, 1968; Liddle et al., 1962; Strott et al., 1969; Jubiz et al., 1970a, and b) to stimulate the release of ACTH by a negative feedback mechanism. Therefore, the "early rise" in plasma ACTH levels after $1.5 \mathrm{~g}$ of metyrapone may not be caused by the negative feedback mechanism. There are a few studies measuring the changes in plasma ACTH within a short period when given a single dose of metyrapone orally. Jubiz et al. (1970a) gave a dose of $750 \mathrm{mg}$ of metyrapone at 8:00 a.m. and found no change in plasma ACTH levels $3 \mathrm{hr}$ later. A similar observation was made by Berson and Yalow (1968), who showed that when the same dose of metyrapone was given at 9:00 a.m., plasma ACTH concentration changed little or continued to 
drop for $2-3 \mathrm{hr}$. Since only 2 out of 6 subjects responded to $1.0 \mathrm{~g}$ of metyrapone in this study, a smaller amount of this drug could not evoke the "early rise" in plasma ACTH levels. Considering together with $\mathrm{GH}$ and $\mathrm{ACTH}$ responses to metyrapone, it is strongly indicated that a higher dose of metyrapone may stimulate the release of both hormones by acting derectly on the pituitary and/or on the hypothalamus within a short period as a non-specific stimulus. The direct effect of metyrapone has been suggested by Ganong and Gold (1960).

A question may arise as to whether or not an increase in plasma ACTH levels after metyrapone reflects the periodic diurnal variation of plasma ACTH reported by Krieger et al. (1971). To exclude this possibility the control experiment should have been performed. We, however, started our experiments at 9:00 a.m., when they reported plasma ACTH levels tended to decrease. A similar tendency was observed in 2 subjects who did not respond to $1.0 \mathrm{~g}$ of metyrapone. Moreover, our results indicate that the stimulatory effect of metyrapone on ACTH release was dose dependent. Therefore, it seems to be possible that metyrapone itself stimulated the release of ACTH.

\section{Acknowledgment}

We are indebted to Drs. Berson and Yalow for the gifts of ACTH preparations for radioiodination and for the reference standard. We are also grateful to the Endocrinology Study Section of the National Institutes of Health for the supply of human GH and anti-human GH serum.

\section{References}

Berson, S. A. and R. S. Yalow (1968). J. Clin. Invest. 47, 2725.

Bruno, O. D., R. Leclercq, E. Virasoro and G. Copinschi (1971). J. Clin. Endocrinol. 32, 260.

Ganong, W. F. and E. M. Gold (1960). Physiologist 3, 21.

Jubiz, W., S. Matsukura, A. W. Meikle, G. Honda, C. D. West and F. H. Tyler (1970a). Arch. Intern. Med. 125, 468.

Jubiz, W., A. W. Meikle, C. D. West and F. H. Tyler (1970b). Ibid. 125, 472.

Krieger, D. T., W. Allen, F. Rizzo and H. P. Krieger (1971). J. Clin. Endocrinol. 32, 266.

Kunita, K., K. Takebe, K. Nakagawa, S. Sawano and Y. Horiuchi (1970). Ibid. 31, 301.

Liddle, G. W. (1960). Ibid. 20, 1539.

Liddle, G. W., D. Island and C. K. Meader (1962). Recent. Progr. Hormone Res. 18, 125.

Rudd, B. T., P. Sampson and B. N. Brooke (1963). J. Endocrinol. 27, 317.

Sawin, C. T., R. F. Spark and M. L. Mitchell (1971). J. Clin. Endocrinol. 32, 854.

Schalch, D. S. and M. Parker (1964). Nature (London) 203, 1141.

Strott, C. A., C. D. West, K. Nakagawa, T. Kondo and F. H. Tyler (1969). J. Clin. Endocrinol. 29, 6.

Zahnd, G. R., A. Nadeau and K. Mühlendahl (1969). Lancet II, 1287. 